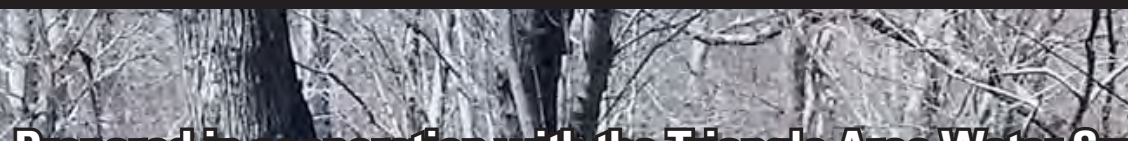

Prepared in cooperation with the Tfiang e Area Water supply Monitoring Project Steerningommittee,

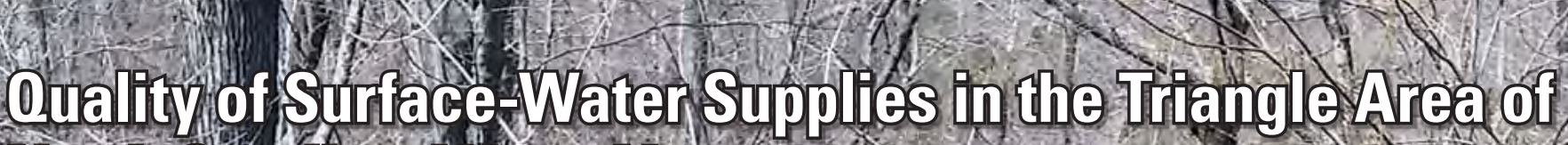
North Car off a, Water Years $2010=21$

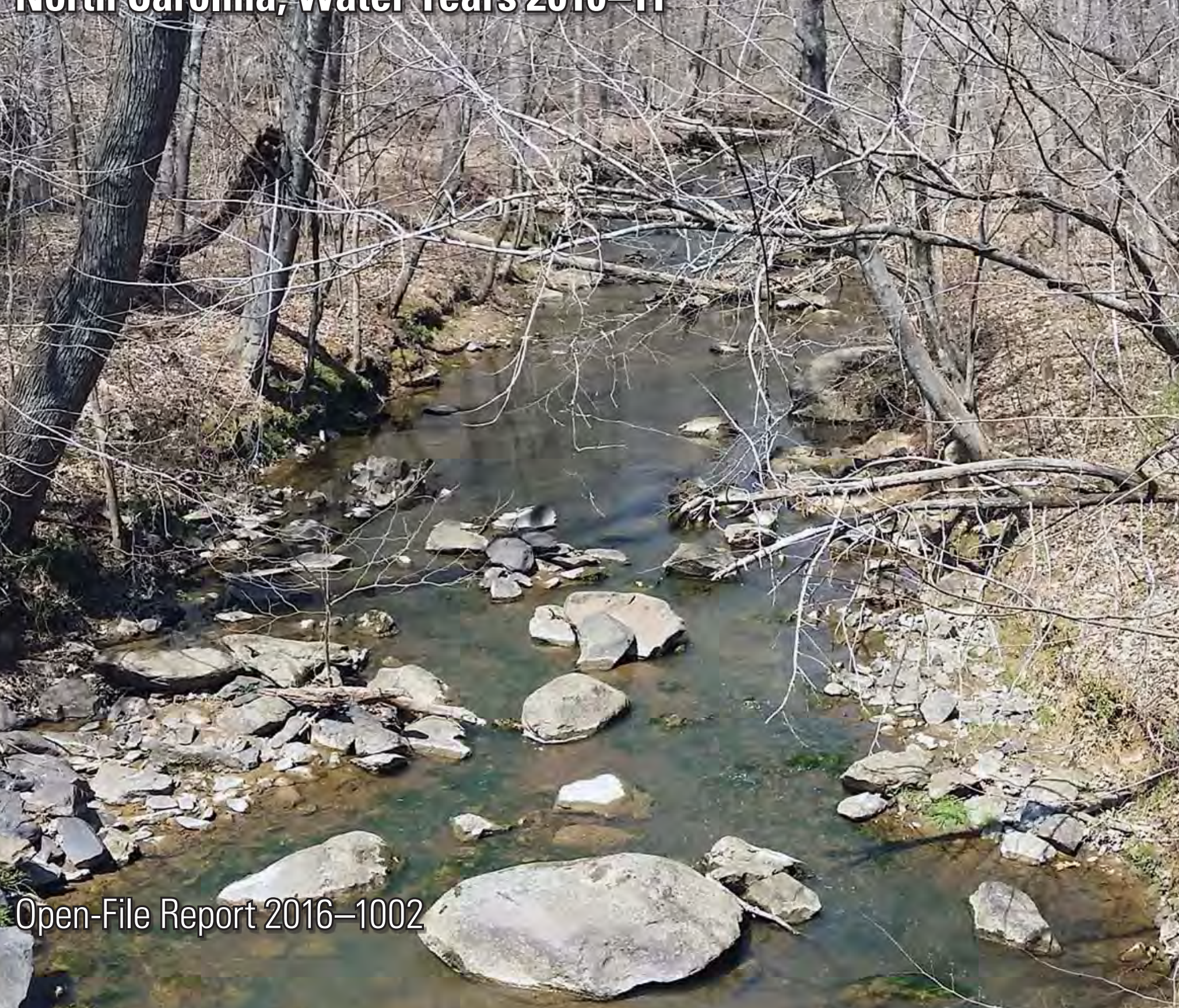

U.S. Department of the lnterior U.S. Geological Survey 
Cover: Cane Creek near Orange Grove, North Carolina. Photograph by Ryan Rasmussen, U.S. Geological Survey. 


\section{Quality of Surface-Water Supplies in the Triangle Area of North Carolina, Water Years 2010-11}

By C.A. Pfeifle, J.L. Cain, and R.B. Rasmussen

Prepared in cooperation with the Triangle Area Water Supply Monitoring Project Steering Committee

Open-File Report 2016-1002 


\section{U.S. Department of the Interior SALLY JEWELL, Secretary}

\section{U.S. Geological Survey Suzette M. Kimball, Director}

U.S. Geological Survey, Reston, Virginia: 2016

For more information on the USGS - the Federal source for science about the Earth, its natural and living resources, natural hazards, and the environment-visit http://www.usgs.gov or call 1-888-ASK-USGS.

For an overview of USGS information products, including maps, imagery, and publications, visit http://www.usgs.gov/pubprod/.

Any use of trade, firm, or product names is for descriptive purposes only and does not imply endorsement by the U.S. Government.

Although this information product, for the most part, is in the public domain, it also may contain copyrighted materials as noted in the text. Permission to reproduce copyrighted items must be secured from the copyright owner.

Suggested citation:

Pfeifle, C.A., Cain, J.L., and Rasmussen, R.B., 2016, Quality of surface-water supplies in the Triangle area of North Carolina, water years 2010-11: U.S. Geological Survey Open-File Report 2016-1002,

19 p., http://dx.doi.org/10.3133/ofr20161002.

ISSN 2331-1258 (online) 


\section{Contents}

Abstract
Introduction
Monitoring Network
Streamflow Gaging Stations
Water-Quality Sites and Constituents
Quality Assurance
Water Quality
Dissolved Oxygen, pH, and Specific Conductance

Appendix 1. Analytical results of field blanks collected during surface-water sampling at theTriangle Area Water Supply Monitoring Project study sites, North Carolina, October 2009 through September 2011 ...............http://dx.doi.org/10.3133/ofr20161002

Appendix 2. Analytical results for the environmental and replicate sample sets collected at the Triangle Area Water Supply Monitoring Project study sites, North Carolina, October 2009 through September 2011 ................http://dx.doi.org/10.3133/ofr20161002

Appendix 3. Water-quality data for surface-water samples collected from October 2009 through September 2011 at the Triangle Area Water Supply Monitoring Project study sites, North Carolina .http://dx.doi.org/10.3133/ofr20161002

Appendix 4. Chemical constituents and physical properties analyzed by the U.S. Geological Survey National Water Quality Laboratory for the Triangle Area Water Supply Monitoring Project and the methods used for sample analyses, October 2009 through September 2011 ..http://dx.doi.org/10.3133/ofr20161002

\section{Figures}

1. Location of Triangle Area Water Supply Monitoring Project data-collection sites in the upper Cape Fear and Neuse River Basins, North Carolina.

2-5. Graphs showing-

2. Monthly precipitation at the Raleigh-Durham International Airport, North Carolina (National Weather Service station KRDU), October 2009 through September 2011

3. Palmer Hydrological Drought Index for the Northern Piedmont and Central Piedmont climate divisions of North Carolina, October 2009 through September 2011

4. Annual runoff measured from October 2009 through September 2010 and October 2010 through September 2011 and the long-term mean runoff for the period of record at 10 streamflow gaging stations in the Triangle area of North Carolina

5. Seven-day average streamflow, in cubic feet per second, overlaid on period of-record flow percentiles at site 2, Eno River at Hillsborough in the Neuse River Basin, and site 20, Haw River near Bynum in the Cape Fear River Basin, for the period October 2009 through September 2011 
6. Maps showing sites in the Triangle area of North Carolina with one or more measurement of dissolved-oxygen concentration less than 5 milligrams per liter and dissolved-oxygen percent saturation values greater than 110 percent, October 2009 through September 2011

7. Maps showing sites in the Triangle area of North Carolina with one or more concentration of unfiltered iron greater than 1,000 micrograms per liter, unfiltered manganese greater than 200 micrograms per liter, unfiltered mercury greater than 0.012 microgram per liter, and unfiltered copper greater than 7 micrograms per liter, October 2009 through September 2010.

8. Graphs showing concentrations of total nitrogen and total phosphorus at sampled sites in the Triangle Area Water Supply Monitoring Project study area,

October 2009 through September 2011

\section{Tables}

1. Water-quality and streamflow monitoring sites for the Triangle Area Water Supply Monitoring Project, North Carolina, October 2009 through September 2011

2. Summary of selected constituent data observed in equipment, vehicle, and field blanks and environmental samples from the Triangle Area Water Supply Monitoring Project, 2010-11

3. Summary of water-quality results for sampled sites in the Triangle Area Water Supply Monitoring Project, October through

September 2011 http://dx.doi.org/10.3133/ofr20161002

\section{Conversion Factors}

Inch/Pound to SI

\begin{tabular}{|c|c|c|}
\hline Multiply & By & To obtain \\
\hline \multicolumn{3}{|c|}{ Length } \\
\hline inch (in.) & 25.4 & millimeter $(\mathrm{mm})$ \\
\hline mile (mi) & 1.609 & kilometer (km) \\
\hline \multicolumn{3}{|c|}{ Flow rate } \\
\hline cubic foot per second $\left(\mathrm{ft}^{3} / \mathrm{s}\right)$ & 0.02832 & cubic meter per second $\left(\mathrm{m}^{3} / \mathrm{s}\right)$ \\
\hline
\end{tabular}

Temperature in degrees Celsius $\left({ }^{\circ} \mathrm{C}\right)$ may be converted to degrees Fahrenheit $\left({ }^{\circ} \mathrm{F}\right)$ as ${ }^{\circ} \mathrm{F}=\left(1.8 \times{ }^{\circ} \mathrm{C}\right)+32$. 


\section{Supplemental Information}

Water year is defined as the period from 0ctober 1 to September 30 and is identified by the year in which the period ends. For example, water year 2010 is 0 ctober 1, 2009, to September 30, 2010.

Specific conductance is given in microsiemens per centimeter at 25 degrees Celsius $\left(\mu \mathrm{S} / \mathrm{cm}\right.$ at $\left.25^{\circ} \mathrm{C}\right)$.

Concentrations of chemical constituents in water are given in either milligrams per liter (mg/L) or micrograms per liter $(\mu \mathrm{g} / \mathrm{L})$.

\section{Abbreviations}

MCL maximum contaminant level

NCDWO North Carolina Division of Water Quality

NWIS National Water Information System

NWOL National Water Quality Laboratory

RPD relative percent difference

SDWR secondary drinking-water regulation

TAWSMP Triangle Area Water Supply Monitoring Project

USGS U.S. Geological Survey 



\title{
Quality of Surface-Water Supplies in the Triangle Area of North Carolina, Water Years 2010-11
}

\author{
By C.A. Pfeifle, J.L. Cain, and R.B. Rasmussen
}

\section{Abstract}

Surface-water supplies are important sources of drinking water for residents in the Triangle area of North Carolina, which is located within the upper Cape Fear and Neuse River Basins. Since 1988, the U.S. Geological Survey and a consortium of local governments have tracked water-quality conditions and trends in several of the area's water-supply lakes and streams. This report summarizes data collected through this cooperative effort, known as the Triangle Area Water Supply Monitoring Project, during October 2009 through September 2010 (water year 2010) and October 2010 through September 2011 (water year 2011). Major findings for this data-collection effort include

- Annual precipitation was approximately 4 percent above the long-term mean (average) annual precipitation in 2010 and approximately 6 percent below the long-term mean in 2011.

- In water year 2010, streamflow was near the long-term mean for most of the period for the 10 project streamflow gaging stations. Streamflow was near or below the long-term mean at the same streamflow gaging stations during the 2011 water year.

- More than 13,000 individual measurements of water quality were made at a total of 28 sites - 17 in the Neuse River Basin and 11 in the Cape Fear River Basin. Forty-three water-quality properties or constituents were measured; North Carolina water-quality standards exist for 21 of these.

- All observations met State water-quality standards for water temperature, hardness, chloride, fluoride, sulfate, nitrate plus nitrite, arsenic, cadmium, chromium, lead, nickel, and selenium.

- State water-quality standards were exceeded one or more times for dissolved oxygen, dissolved oxygen percent saturation, $\mathrm{pH}$, copper, iron, manganese, mercury, silver, and zinc. Exceedances occurred at 27 sites - 17 in the Neuse River Basin and 10 in the Cape Fear River Basin.
- Stream samples collected during storm events contained elevated concentrations of 25 water-quality constituents relative to non-storm events.

\section{Introduction}

The Triangle area, located within the upper Cape Fear and Neuse River Basins, is one of the most rapidly developing areas of North Carolina. Population growth continues to increase demands for water from public suppliers, the majority of which draw water from streams and lakes in the region. Growth also brings the threat of greater loads of pollutants and new contaminant sources which, if not properly managed, could adversely affect water quality.

For more than 25 years, the Triangle Area Water Supply Monitoring Project (TAWSMP) has tracked water-quality conditions and long-term trends in many of the area's watersupply lakes, rivers, and tributaries. The project has progressed in phases, allowing for flexibility in the monitoring network and partners, and for timely response to emerging waterquality concerns (http://nc.water.usgs.gov/projects/triangle/ overview.html). Objectives of the project for water years 2010 and 2011 were to

- Extend the existing water-quality database for nutrients, sediment, major ions, and metals and trace elements to track spatial variations in water quality, loads to reservoirs, and long-term water-quality trends.

- Continue monitoring at tributary sites during high-flow events to increase the understanding of constituent concentrations and loads during extreme hydrologic conditions.

- Maintain a network of 10 continuous streamflow gaging stations in the study area.

Pursuant to an agreement with several local governments, the U.S. Geological Survey (USGS) monitors hydrologic conditions and collects water-quality samples in the Triangle area. One site consists only of a streamflow gage. Continuous streamflow is recorded at almost all of the stream sites, and 
data collection is funded through the TAWSMP and other USGS programs. The USGS is responsible for data quality assurance, analysis, and interpretation, providing the data to the public, and maintaining the data in perpetuity. Funding for the project is provided by local government partners (see sidebar) and by the USGS Cooperative Water Program (http://water.usgs.gov/coop/). The Triangle J Council of Governments provides organizational support services for the TAWSMP.

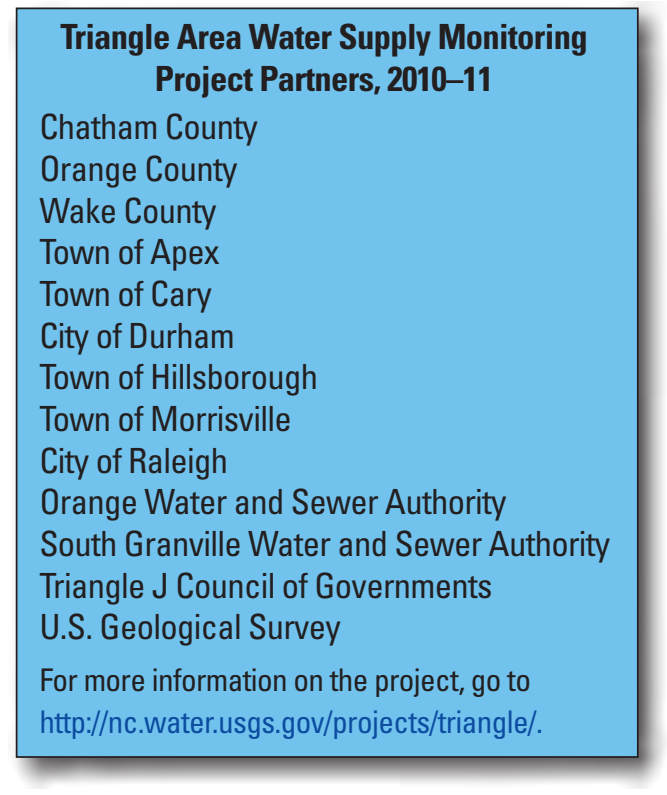

This report summarizes monitoring activities and data collected by the USGS for the TAWSMP during October 2009 through September 2011, also referred to as water years 2010 (October 2009 to September 2010) and 2011 (October 2010 to September 2011). Hydrologic conditions in the Triangle area are described. Ranges of concentrations for water-quality field parameters, major ions, nutrients, metals and trace elements, organic carbon, and suspended sediment are presented for each site sampled during this period.

\section{Monitoring Network}

Since the project began in 1988, several adjustments have been made to sampling locations, sampling frequency, and constituents that are sampled. During 2010-11, the TAWSMP monitoring network comprised 32 sites, including streamflow gaging stations and stream and lake water-quality sampling sites (fig. 1). Water-quality samples were collected at 28 sites during this period. Beginning in July 2011, seven sites were removed from the monitoring network, and analysis of color was discontinued at all sites. Project sampling and analytical methods and quality-assurance practices are described by Oblinger (2004).

\section{Streamflow Gaging Stations}

Streamflow records are useful for managing water supplies and are essential for determining instream loads of sediment, nutrients, and other constituents and interpreting water-quality trends. The USGS operates 10 continuousrecord streamflow gaging stations that are funded through the TAWSMP (table 1). These gages report water level and discharge at 15-minute intervals and display them in near-real time through the USGS National Water Information System (NWISWeb) interface (http://waterdata.usgs.gov/nc/nwis/ current/?type=flow). Precipitation and streamflow data for additional sites in the study area are available through other USGS programs (table 1).

\section{Water-Quality Sites and Constituents}

Water-quality data are used to track current conditions and to analyze long-term water-quality trends and pollutant loads in the Triangle area. The USGS monitored water quality at 28 sites in the TAWSMP study area during water years 2010 and 2011. More than 13,000 individual measurements of water quality were made, not including lake vertical-profile data. The measurements were made at 17 sites in the Neuse River Basin and 11 sites in the Cape Fear River Basin. USGS water-quality data are available to project partners and the public via the NWISWeb (http://nwis.waterdata.usgs.gov/nc/ nwis/qwdata) or by request from the USGS South Atlantic Water Science Center (http://nc.water.usgs.gov/).

Ten public water-supply lakes were sampled bimonthly, including West Fork Eno Reservoir, Little River Reservoir, Lake Michie, Lake Butner, Falls Lake, Lake Wheeler, and Lake Benson in the Neuse River Basin, and Cane Creek Reservoir, University Lake, and Jordan Lake in the Cape Fear River Basin (table 1; fig. 1). Falls and Jordan Lakes are large, multipurpose reservoirs managed by the U.S. Army Corps of Engineers. The USGS sampled four sites in Falls Lake and four sites in Jordan Lake bimonthly during water years 2010 and 2011. Sampling ended for the four sites in Falls Lake in June of 2011. The eight smaller reservoirs are used primarily for water supply though most also provide recreational access. One site in each of the seven smaller lakes was sampled four times per year. Lake samples were collected at multiple depths, but only near-surface samples were summarized in this report. Vertical profiles of field parameters (water temperature, dissolved oxygen, specific conductance, and $\mathrm{pH}$ ) were measured at 1-meter depth intervals at the sampling location, as well as water transparency by Secchi disk depth measurements. Water-quality samples were collected for analysis of color, alkalinity, dissolved and total nutrients, dissolved major ions (calcium, magnesium, sodium, potassium, chloride, fluoride, sulfate, and silica), dissolved iron, dissolved manganese, total organic carbon, phytoplankton, and chlorophyll $a$ during each sampling trip (Oblinger, 2004). Additional water-quality samples were collected for total metals and trace elements 


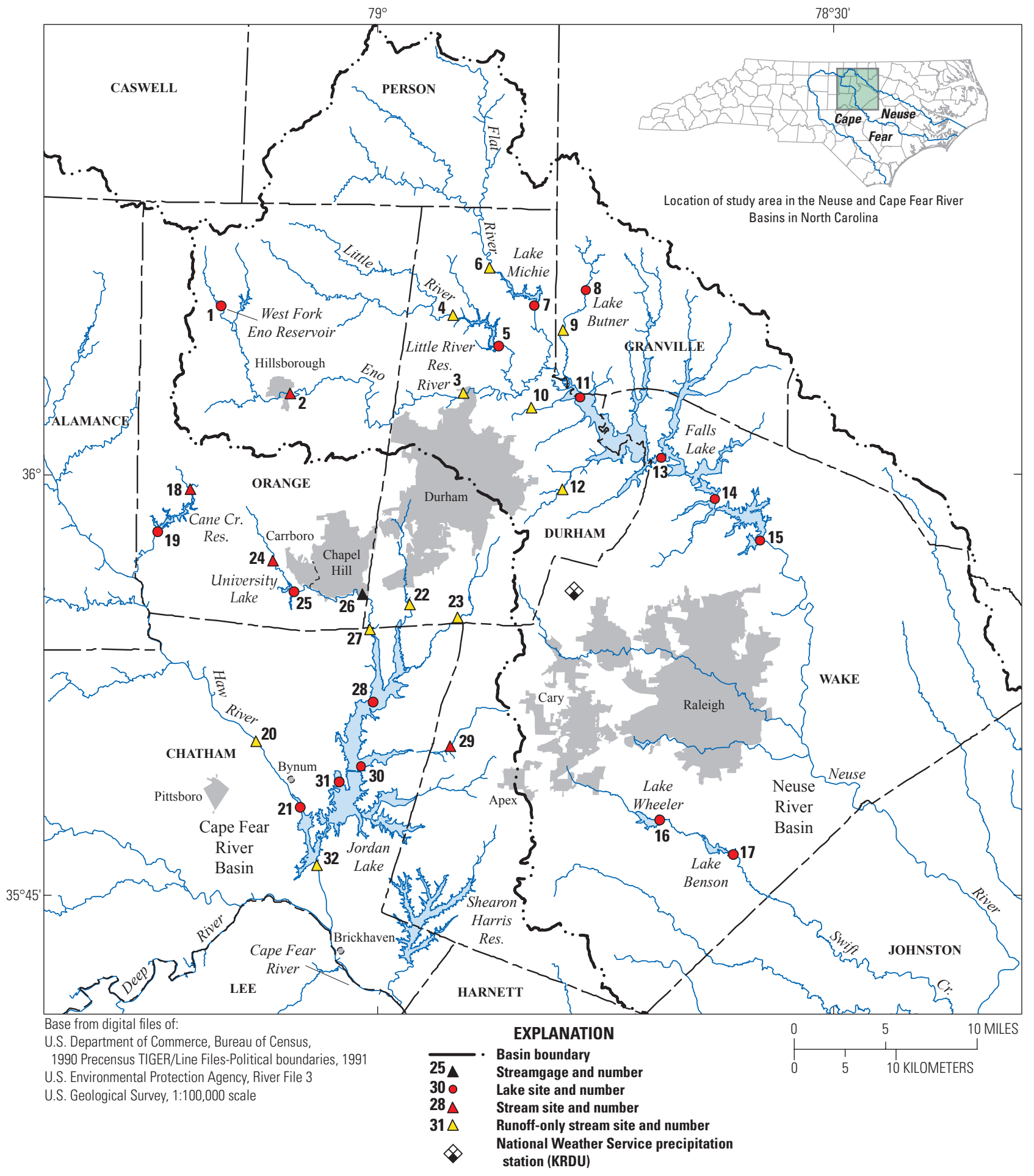

Figure 1. Location of Triangle Area Water Supply Monitoring Project data-collection sites in the upper Cape Fear and Neuse River Basins, North Carolina. 
Table 1. Water-quality and streamflow monitoring sites for the Triangle Area Water Supply Monitoring Project, North Carolina, October 2009 through September 2011.

[USGS, U.S. Geological Survey; Lake, lake sites that were sampled bimonthly; stream runoff, stream sites that were sampled only during runoff events; stream (routine), stream sites that were sampled bimonthly and during runoff; n/a, not applicable for lake sites; --, data were not collected (refer to footnote); USACE, U.S. Army Corps of Engineers; italics indicate site is located in waters listed as impaired by the North Carolina Department of Environment and Natural Resources, Division of Water Quality (2010a) at the time of sampling]

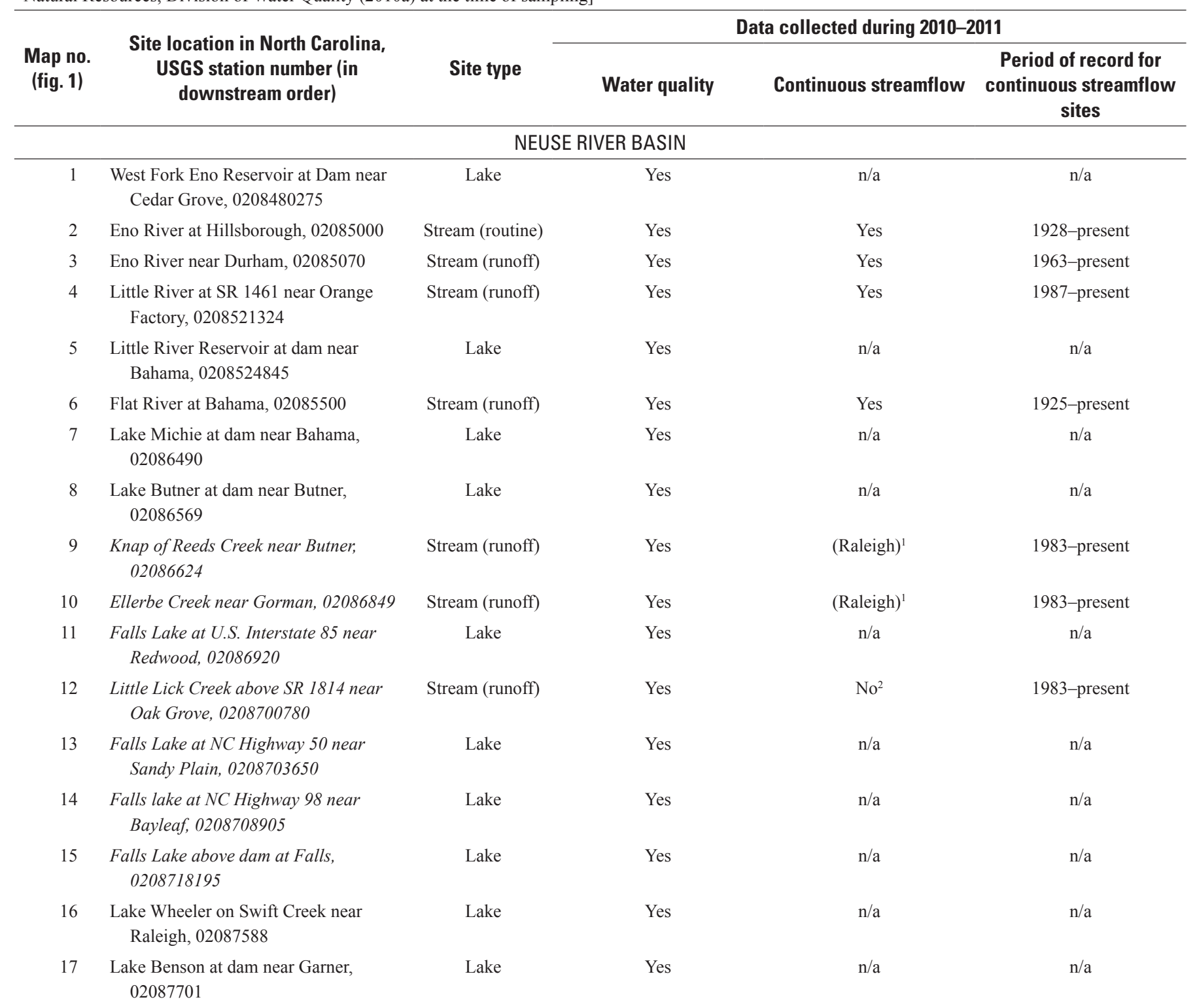


Table 1. Water-quality and streamflow monitoring sites for the Triangle Area Water Supply Monitoring Project, North Carolina, October 2009 through September 2011.-Continued

[USGS, U.S. Geological Survey; Lake, lake sites that were sampled bimonthly; stream runoff, stream sites that were sampled only during runoff events; stream (routine), stream sites that were sampled bimonthly and during runoff; $n / a$, not applicable for lake sites; --, data were not collected (refer to footnote); USACE, U.S. Army Corps of Engineers; italics indicate site is located in waters listed as impaired by the North Carolina Department of Environment and Natural Resources, Division of Water Quality (2010a) at the time of sampling]

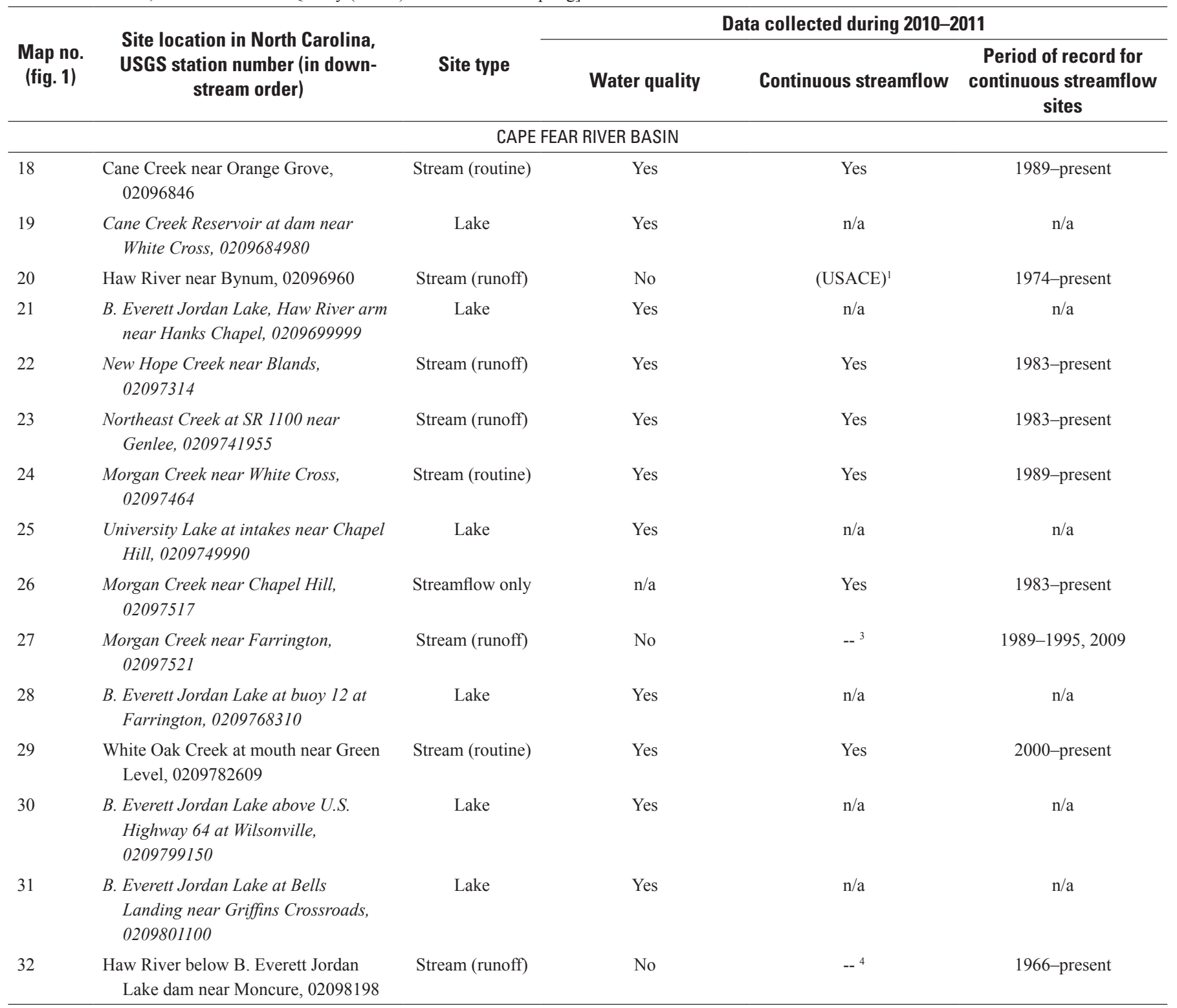

\footnotetext{
${ }^{1}$ Gage funded through separate agreement with agency shown in parentheses.

${ }^{2}$ Instantaneous streamflow measured during sampling.

${ }^{3}$ Streamflow from nearby gage, USGS station 02097517.

${ }^{4}$ Streamflow computed from USACE releases from the Jordan Lake dam.
} 
(aluminum, arsenic, cadmium, chromium, cobalt, copper, zinc, lead, mercury, molybdenum, nickel, selenium, and silver) twice per year.

Four stream sites were sampled by the USGS on a bimonthly basis for field parameters, color, nutrients, major ions, total organic carbon, and suspended sediment, and twice per year for metals and trace elements. These sites include Eno River at Hillsborough, Cane Creek near Orange Grove, Morgan Creek near White Cross, and White Oak Creek (fig. 1; table 1). Samples were taken at multiple locations along a transect and were composited. Sampling is not conducted during zero-flow conditions, which occasionally occurs at the smaller streams.

In addition to the bimonthly sampling at the 4 stream sites, an additional 11 stream sites in the TAWSMP network were considered for sampling only during storm-runoff events when water level was rapidly increasing due to a localized rainfall event (fig.1; table 1). The actual number of sampled sites varied from year to year. During 2010-11, eight additional stream sites were targeted for sampling by the USGS only during selected storm-runoff events. These higher-flow samples supplement fixed-interval data collected as part of the North Carolina Division of Water Quality (NCDWQ) Ambient Monitoring System (http://portal.ncdenr.org/web/wq/ess/eco/ams).

Six runoff samples were collected using a portable refrigerated automatic sampler at Little River (site 4; one sample), Knap of Reeds Creek (site 9; one sample), Ellerbe Creek (site 10; three samples), and Cane Creek (site 18; one sample) according to USGS protocols (U.S. Geological Survey, 2006). Once the pre-programmed water-level condition for the stream was met, seven individual 1-liter (L) polyethylene bottles were consecutively filled with sample water by the automatic sampler. After sampling was completed, the refrigerated automatic sampler maintained the samples at a temperature of 3 degrees Celsius $\left({ }^{\circ} \mathrm{C}\right.$; minus or plus $\left.1{ }^{\circ} \mathrm{C}\right)$. The seven individual 1-L bottles were retrieved, and the contents of the bottles were combined and composited into an 8 -L plastic churn splitter. The samples were processed within 24 hours of collection using the same processing techniques as used for manual or routine samples (Wilde and others, 2004). Because the delay between collection and processing allowed conditions within the collection bottles to deviate from those measured instream, dissolved oxygen and water temperature measurements from the composite samples were not recorded. If the automatic sampler did not collect enough water, some constituents were not analyzed at the laboratory.

Alkalinity was determined in the field at the time of sampling, using USGS standard methods (Rounds, 2012). Water-quality samples were analyzed for suspended sediment concentrations at the USGS Eastern Region Sediment Laboratory in Louisville, Kentucky. Nutrient, major ion, and trace element analyses were performed at the USGS National Water Quality Laboratory (NWQL) in Denver, Colorado. The NWQL participated in two chlorophyll $a$ inter-laboratory performance comparisons (round robins) sponsored by the NCDWQ during 2010 and 2011. The chlorophyll $a$ concentrations analyzed at the NWQL were routinely biased low compared to analyses by the other participants. Therefore, the 2010-11 chlorophyll $a$ data analyzed by the NWQL are not included in this report.

During water years 2010 and 2011, routine sampling of the 16 lake sites and the 4 stream sites sampled bimonthly was conducted on schedule with a few exceptions. Falls Lake at U.S. Interstate 85 (site 11) was inaccessible during multiple attempts in December 2010 because the lake was frozen. Due to the low water conditions observed at Cane Creek near Orange Grove (site 18), Morgan Creek near White Cross (site 24), and White Oak Creek near Green Level (site 29) during August 2011, routine samples were not collected. In September 2011, a routine sample was collected at White Oak Creek after flow conditions improved. A total of 22 runoffevent samples were collected among the four routine stream sites and eight runoff-only stream sites. It is important to note that results for the eight streams sampled only during runoff events likely do not represent typical water-quality conditions for these streams.

\section{Quality Assurance}

Quality-control samples, consisting of deionized-water blanks, sampling-equipment blanks, sampling-vehicle (ambient) blanks, field blanks, and replicate samples, were collected and reviewed throughout the period to ensure that project data-quality objectives were met (appendixes 1, 2; Oblinger, 2004). Deionized water was produced in the USGS Raleigh laboratory and was used to clean sampling equipment. The source solution for sampling-equipment, sampling-vehicle, and field blanks was inorganic-blank or organic-blank water (depending on the constituents to be analyzed) obtained from the USGS National Field Service Supply. Approximately 11 percent of the sample load consisted of quality-control samples. Quality-control samples and collection procedures are described in chapter 4 of the USGS National Field Manual (U.S. Geological Survey, 2006).

During October 2009 through September 2011, 3 deionized-water blanks, 3 sampling-equipment blanks, 12 sampling-vehicle blanks, and 11 field blanks were collected and analyzed for major ions, nutrients, trace metals, and total organic carbon (appendix 1). In all, 30 constituents were analyzed and 806 blank results were generated. Almost 95 percent of the results were below reporting levels, indicating minimal contamination during this period. In all, 30 quantified blank results were detected (results above constituent reporting levels), which represented approximately 4 percent of the results.

Deionized-water and sampling-equipment blanks had no quantified detections. Therefore, contamination due to the equipment cleaning process or laboratory analysis was unlikely. In contrast, three vehicle blanks and eight field blanks had quantified detections of one or more constituents, indicating that contamination was more likely to occur during field sampling and processing (appendix 1). 
Thirteen constituents had one or more quantified detections. A detection rate of 10 percent was deemed acceptable for this study. If a constituent was detected in greater than 10 percent of the combined equipment, vehicle, and field blanks, then the results were assessed for the potential to positively bias the environmental results. Only five constituents exceeded the 10 percent blank-detection threshold, including chloride, ammonia, cobalt, manganese, and total organic carbon (table 2).

Of the eight major ions analyzed, only chloride (16 percent) was detected in greater than 10 percent of the blanks. All quantified detections for chloride occurred in the field blanks. Four of the six nutrient species had quantified detections in at least one of the blanks. Of these, only ammonia (19 percent) had detectable concentrations in greater than 10 percent of the blanks, the majority of which were field blanks. Seven of the 15 trace metals had detectable concentrations in at least one of the blanks, but only cobalt (22 percent) was detected in greater than 10 percent of the blanks, the majority of which were field blanks. Approximately 12 percent of the blanks for total organic carbon, which were all field blanks, had quantified detections (table 2).

Detected environmental samples with concentrations less than five times the median value of the quantified blank detections were considered to have a reasonable potential for contamination. Therefore, detected concentrations in environmental samples of chloride less than 4.4 milligrams per liter $(\mathrm{mg} / \mathrm{L})$, ammonia less than $0.05 \mathrm{mg} / \mathrm{L}$, cobalt less than $0.60 \mathrm{mg} / \mathrm{L}$, manganese less than $10.5 \mathrm{mg} / \mathrm{L}$, and total organic carbon less than $5.0 \mathrm{mg} / \mathrm{L}$ may be positively biased due to contamination during field sampling activities. These threshold values represent five times the median concentration of the quantified blank detections. More than 70 percent of the environmental sample results for cobalt were potentially biased and therefore should be interpreted with caution. Approximately 41 percent of the environmental sample results for ammonia were potentially biased. In contrast, only 5 percent of the chloride concentrations and 4 percent of the total organic carbon concentrations for the environmental samples were potentially affected. Concentrations of manganese in all environmental samples were higher than the threshold and likely were not biased by contamination (table 2).

The variability of sampling and analysis was assessed with 19 sets of field replicates (appendix 2). Among the 19 sets of field replicates, there were a total of 215 replicateresult pairs. Paired concentrations with a relative percent difference (RPD, absolute difference times 100 divided by the average) less than 25 percent were considered to demonstrate acceptable reproducibility. Of the 215 replicate set pairs, approximately 96 percent had RPDs less than 25 percent.

Ammonia plus organic nitrogen, ammonia, total phosphorus, total nitrogen, copper, lead, mercury, and suspended sediment each had a single replicate set with a RPD greater than 25 percent (appendix 2). Large RPD values are common and accepted without further discussion when they result from small absolute differences near the reporting level for the constituent. For example, one ammonia replicate set had a RPD of 66.7; however, the absolute difference was $0.01 \mathrm{mg} / \mathrm{L}$, and the reporting level was $0.01 \mathrm{mg} / \mathrm{L}$, so the difference is considered to be negligible. When the absolute concentration difference is greater than or equal to three times the reporting level and is associated with a large RPD, high variability is indicated. Only one replicate pair for suspended sediment met these criteria, with a RPD of 100 percent and an absolute difference of $4 \mathrm{mg} / \mathrm{L}$. Samples for unfiltered constituents such as suspended sediment are inherently more variable, so this was an isolated occurrence. Likewise, the isolated occurrences of high RPDs for ammonia plus organic nitrogen, total phosphorus, total nitrogen, copper, lead, and mercury were not representative of the dataset as a whole. In general, results for replicate pairs indicated acceptable reproducibility for all water-quality constituents measured during the study period. 


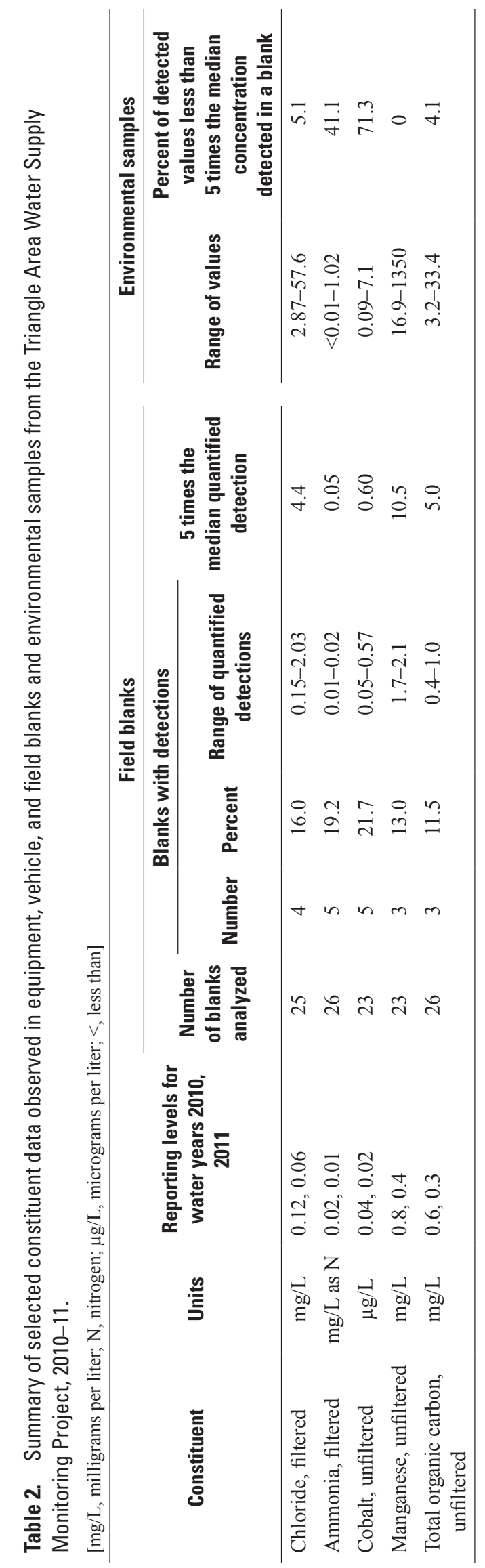




\section{Precipitation and Streamflow}

Precipitation measured at the Raleigh-Durham International Airport, North Carolina (National Weather Service station KRDU) (fig. 1), from October 2009 through September 2010 totaled 45.0 inches, which is approximately 4 percent above the long-term mean annual precipitation of 43.1 inches (State Climate Office of North Carolina, 2012b). However, from October 2010 through September 2011, precipitation at the Raleigh-Durham Airport measured 40.6 inches, which is approximately 6 percent below the long-term mean annual precipitation. The highest monthly precipitation for the 2-year period occurred in August 2011 (8.8 inches) (fig. 2).
Another indication of hydrologic conditions is provided by the monthly Palmer Hydrological Drought Index scores for water years 2010 and 2011 (fig. 3; State Climate Office of North Carolina, 2012a). This index reflects the long-term, cumulative impacts of drought on hydrologic characteristics such as reservoir levels and streamflow. Negative values indicate dry periods, and positive values indicate wet periods. The Palmer Hydrological Drought Index is separated into 11 categories as defined by Palmer (1965). Among these categories are values greater than or equal to 4.00 which are classified as extremely wet; near normal conditions are considered to be from 0.49 to -0.49 ; and extreme drought conditions are considered to be less than or equal to -4.00 . The Palmer Hydrological Drought Index indicated that mild

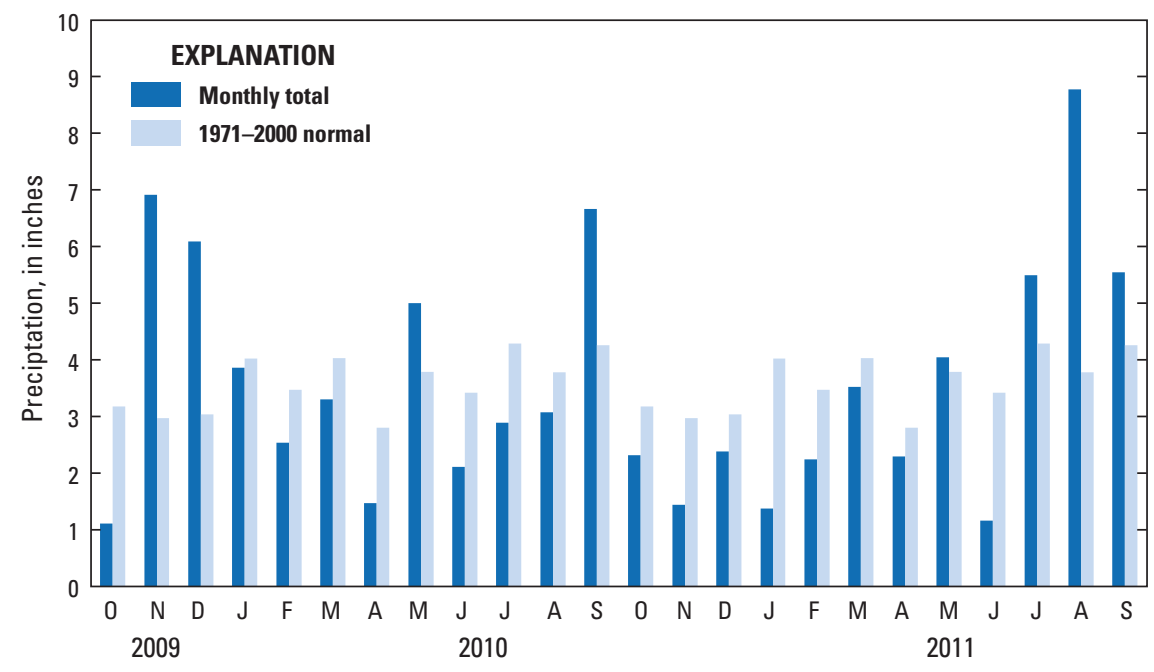

Figure 2. Monthly precipitation at the Raleigh-Durham International Airport, North Carolina (National Weather Service station KRDU), October 2009 through September 2011 (from State Climate Office of North Carolina, 2012b). (Station location is shown in figure 1.)

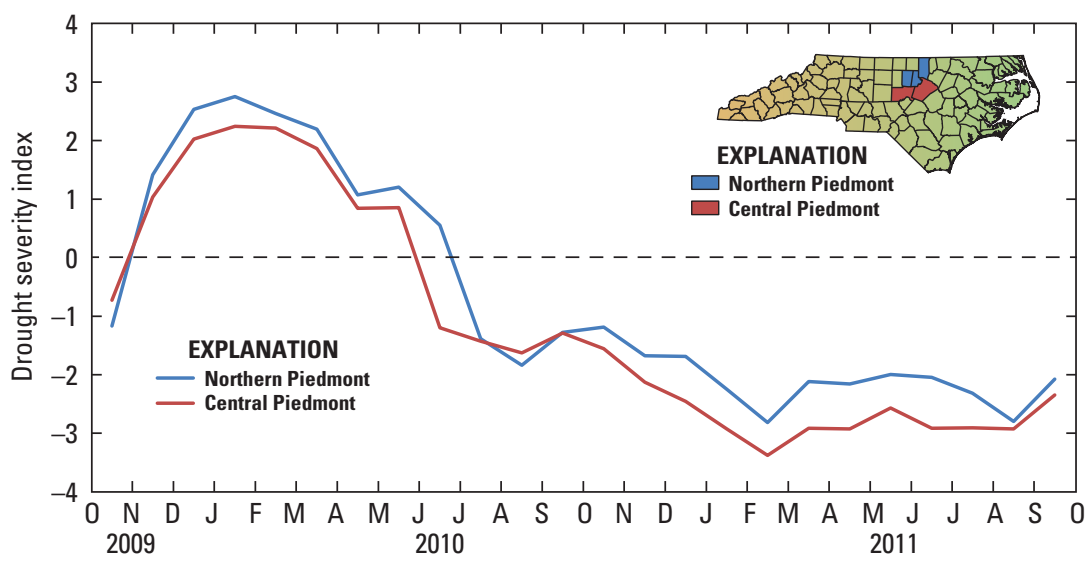

Figure 3. Palmer Hydrological Drought Index for the Northern Piedmont and Central Piedmont climate divisions of North Carolina, October 2009 through September 2011. Values above zero indicate wet periods, and values below zero indicate dry periods. 
drought conditions continued during October 2009 in the Northern Piedmont (including Orange, Durham, and Granville Counties) as reported at the end of water year 2009 (Pfeifle and others, 2014). From November 2009 through June 2010, conditions ranged from an incipient wet spell to moderately wet. Mild to moderate drought conditions prevailed in the Northern Piedmont beginning in July 2010 and continuing through the end of water year 2011. In the Central Piedmont (including Chatham and Wake Counties) of North Carolina (fig. 3), incipient drought conditions persisted through October 2009. Incipiently wet to moderately wet conditions were seen in the region from November 2009 through May 2010, and mild to severe drought conditions were seen in the Central Piedmont through the remainder of water years 2010 and 2011.

Streamflow data collected at all 10 TAWSMP gaging stations were reviewed, quality assured, and published in the USGS Water Data Reports for water years 2010 and 2011 (http://nc.water.usgs.gov/reports/WDR/). Detailed data also are available online via the USGS NWISWeb (http://waterdata.usgs.gov/nc/nwis/).

Annual runoff in water year 2010 was above long-term mean at all gaging stations (fig. $4 A$ ) except for Eno River at Hillsborough (site 2), New Hope Creek near Blands (site 22), and Morgan Creek near White Cross (site 24), which were below long-term mean. Annual runoff for water year 2010 ranged from 10.15 to 22.45 inches among the 10 stations. Annual runoff in water year 2011 was below long-term mean at all gaging stations (fig. $4 B$ ). At the 10 gaging stations, annual runoff in water year 2011 ranged from 1.72 to 16.27 inches. At some sites, including New Hope Creek near Blands (site 22), Northeast Creek near Genlee (site 23), and Morgan Creek near Chapel Hill (site 26), a significant percentage of the instream flow consisted of treated effluent from municipal water reclamation facilities. These continuous inputs contributed to higher instream flows and tended to mitigate the effects of drought on annual runoff (fig. 4).

During most of water year 2010, streamflow conditions were generally near the normal range, as illustrated by 7-day average hydrographs for the Eno River at Hillsborough (site 2) in the Neuse River Basin and the Haw River near Bynum (site 20) in the Cape Fear River Basin (fig. 5). Streamflow conditions were near or below the normal range for the majority of water year 2011 (fig. 5). Three streams in the study area had periods of zero-flow during water years 2010 and 2011. No-flow periods occurred at Cane Creek near Orange Grove (site 18), Morgan Creek near White Cross (site 24), and White Oak Creek near Green Level (site 29) as seen in previous water years (Giorgino and others, 2012; Pfeifle and others, 2014).

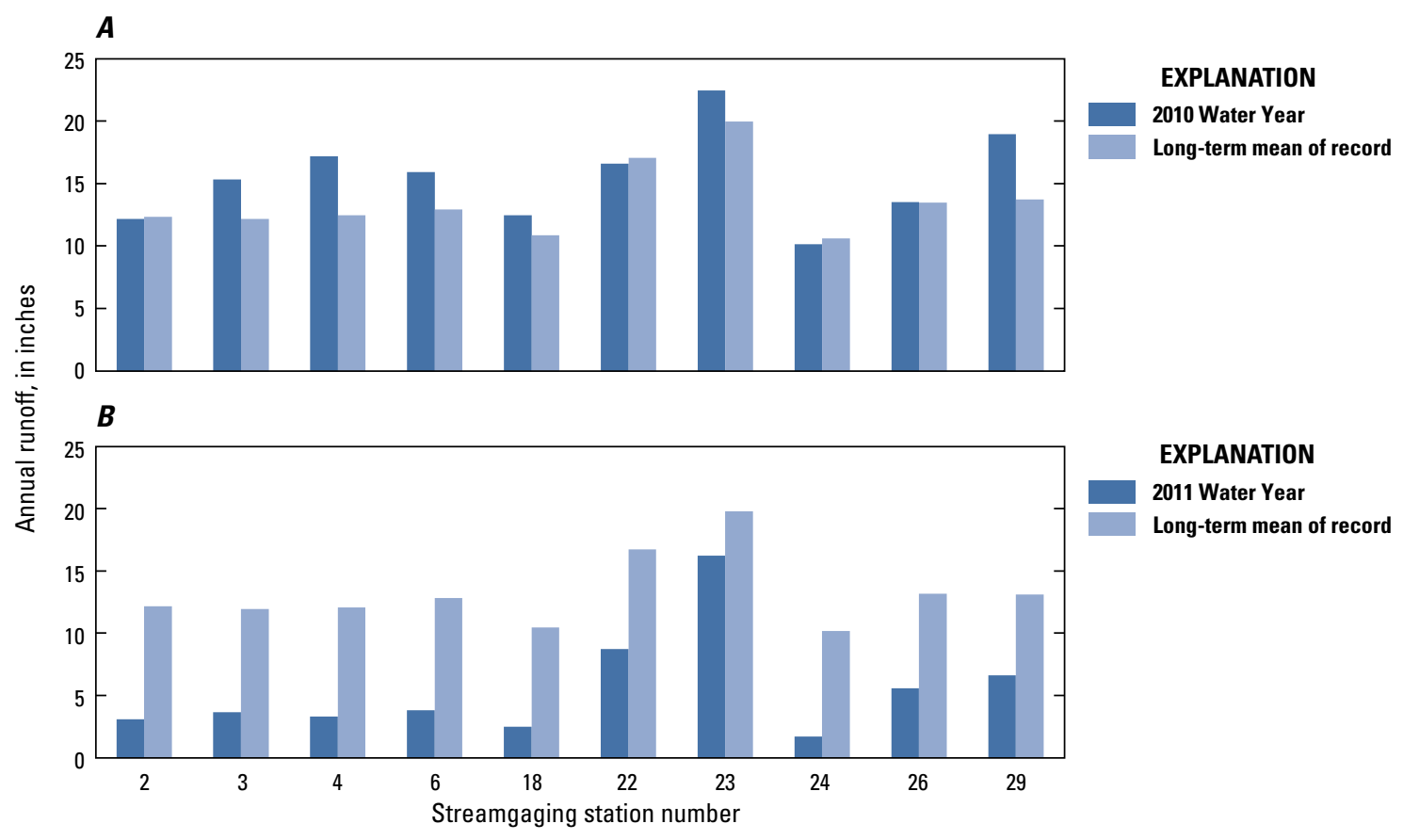

Figure 4. Annual runoff measured from $A, 0$ ctober 2009 through September 2010 and $B$, October 2010 through September 2011 and the long-term mean runoff for the period of record at 10 streamflow gaging stations in the Triangle area of North Carolina. The period of record varies among stations (see table 1). 


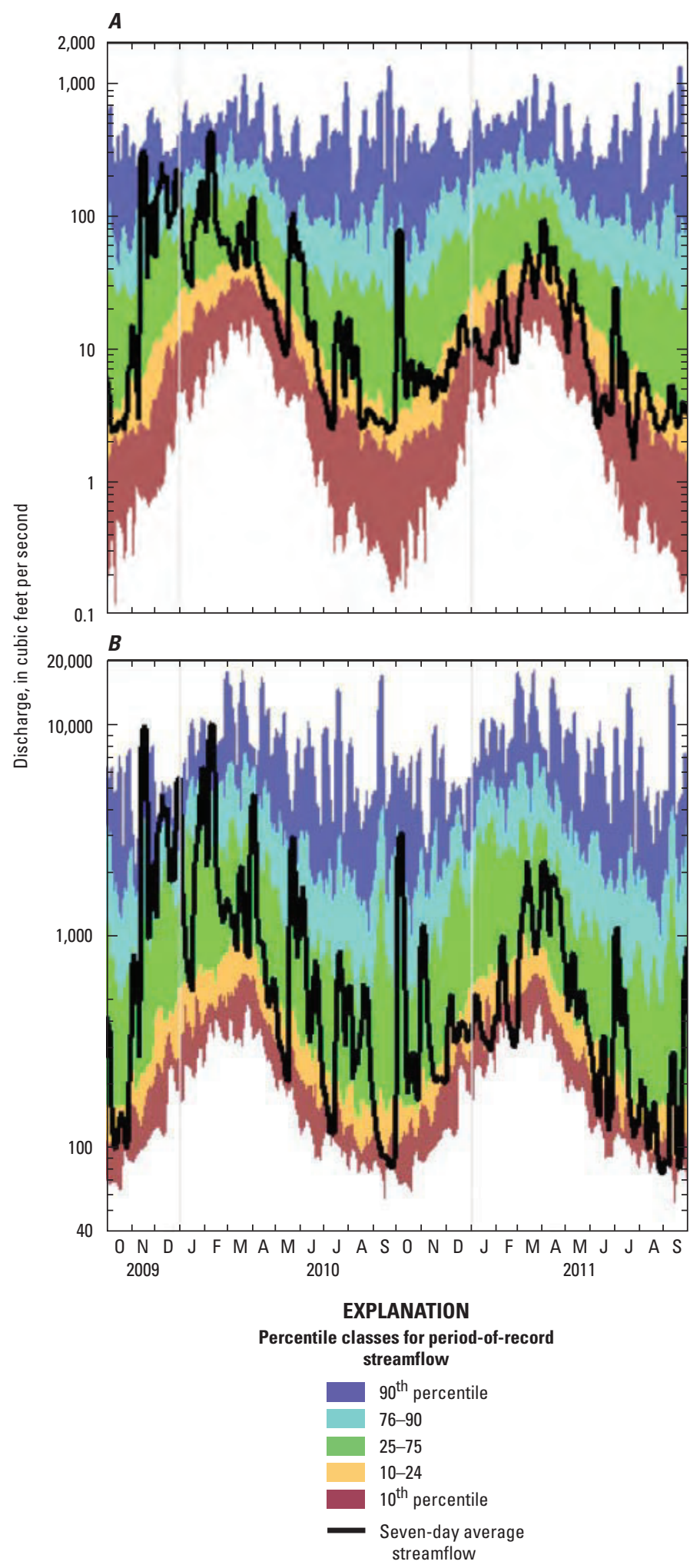

Figure 5. Seven-day average streamflow, in cubic feet per second, overlaid on period-of-record flow percentiles at $A$, site 2, Eno River at Hillsborough in the Neuse River Basin, and B, site 20, Haw River near Bynum in the Cape Fear River Basin, for the period October 2009 through September 2011. (See table 1; station locations are shown in figure 1.) 


\section{Water Quality}

Water-quality data were reviewed, quality assured, and published in the USGS 2010 and 2011 Water Data Reports (http://nc.water.usgs.gov/reports/WDR/). The data are presented in appendix 3 and also are available online via the USGS NWISWeb (http://waterdata.usgs.gov/nc/ nwis/). Ranges of concentrations observed at each site for 43 properties or constituents are presented (table 3). Analytical methods used for all measured properties and constituents are presented in appendix 4. Dissolved oxygen percent saturation, hardness, and total nitrogen were computed by using USGS National Water Information System (NWIS) algorithms. Although the USGS samples lake sites at multiple depths, only results from near-surface waters are summarized in this report. Additional data for lake samples collected at mid-depth or in near-bottom waters may be obtained from the NWISWeb or by request to the USGS South Atlantic Water Science Center (http://nc.water.usgs.gov).

Instream water-quality standards have been adopted by the North Carolina Division of Water Quality for 21 constituents monitored by the TAWSMP (table 3 ). All project sampling sites are classified for water-supply use; therefore, applicable standards are the most stringent values established to protect freshwater aquatic life, water supply, or human health (North Carolina Department of Natural Resources, Division of Water Quality, 2007). It is of note that individual observations that do not meet water-quality thresholds do not constitute violations of the standards, nor indicate that the body of water is impaired. However, the thresholds are useful for comparative purposes.

Concentration ranges shown in table 3 in bold text indicate that at least one sample for the constituent exceeded a North Carolina water-quality threshold at that location. Water-quality exceedances occurred at 17 sites in the Neuse River Basin and at 10 sites in the Cape Fear River Basin. Maximum Contaminant Levels (MCLs) and Secondary Drinking Water Regulations (SDWRs) have been established by the U.S. Environmental Protection Agency for 19 of the constituents measured (U.S. Environmental Protection Agency, 2015). These criteria are applicable only to treated potable water - not to raw water supplies - and are provided solely for reference.

All observations met State water-quality thresholds for 12 constituents including temperature, hardness, chloride, fluoride, sulfate, nitrate, arsenic, cadmium, chromium, lead, nickel, and selenium. Values exceeded thresholds for nine water-quality constituents, including dissolved oxygen, dissolved oxygen percent saturation, $\mathrm{pH}$, copper, iron, manganese, mercury, silver, and zinc (table 3). Jordan Lake above U.S. Highway 64 (site 30) was the only site during water years 2010 and 2011 that met all water-quality thresholds for the constituents that were measured.

Stream samples collected during runoff events contained more particulate material than samples collected during routine sampling events. As might be expected, runoff samples had higher concentrations of unfiltered constituents than non-runoff samples, including total nitrogen; ammonia plus organic nitrogen; total phosphorus; total organic carbon; total recoverable aluminum, arsenic, chromium, cobalt, copper, iron, lead, manganese, mercury, molybdenum, nickel, silver, selenium, and zinc; and suspended sediment. In addition, several filtered constituents were relatively higher in runoff samples, including potassium, fluoride, ammonia, nitrate plus nitrite, nitrite, and orthophosphate. Comparisons were based on the Wilcoxon rank test $(\mathrm{p}<0.05)$.

\section{Dissolved Oxygen, pH, and Specific Conductance}

Dissolved-oxygen concentrations less than the State daily-average minimum threshold of $5 \mathrm{mg} / \mathrm{L}$ were observed occasionally at five lake sites and one stream site in the study area (table 3; fig. 6A). Dissolved-oxygen concentrations less than the instantaneous minimum threshold of $4.0 \mathrm{mg} / \mathrm{L}$ were recorded at Lake Michie (site 7) in October 2009 (3.5 mg/L) and at Falls Lake at U.S. Interstate 85 (site 11) in August 2010 (3.4 mg/L). Dissolved-oxygen concentrations less than $4.0 \mathrm{mg} / \mathrm{L}$ also were observed at Morgan Creek near White Cross (site 24) on October 5, 2009 (1.6 mg/L), August 6, 2010 $(1.0 \mathrm{mg} / \mathrm{L})$, and June 30, $2011(2.4 \mathrm{mg} / \mathrm{L})$.

Dissolved-oxygen concentrations in lakes and rivers are dynamic, fluctuating with temperature, atmospheric pressure, and biological activity. When dissolved oxygen in water is in equilibrium with the air, the water is considered saturated. Under certain conditions, algae and aquatic plants produce oxygen through photosynthesis more rapidly than can be equilibrated with the atmosphere, resulting in supersaturated conditions. Supersaturation is commonly observed in biologically productive lakes, especially during summer months. Dissolved-oxygen saturation values greater than 110 percent exceed the State dissolved-gases threshold; such values were recorded at eight reservoir sites during water years 2010 and 2011 (table 3; fig. 6B). A dissolved-oxygen saturation value greater than 110 percent also was measured at Morgan Creek near White Cross (site 24; 116 percent, April 1, 2010).

Recorded $\mathrm{pH}$ values were within the State's acceptable range of 6.0 to 9.0 standard units, except for four observed values. Values less than 6.0 were measured at Little River (site 4; 5.8 standard units, November 11, 2009), Cane Creek (site 18; 5.8 standard units, March 30, 2011), and White Oak Creek near Green Level (site 29; 5.8 standard units, August 5, 2010). Values greater than 9.0 standard units were measured at Jordan Lake, Haw River arm (site 21, 9.1 standard units, August 17, 2010).

Although no standard has been adopted for specific conductance, this constituent continued to show interesting variations among sites. The highest conductance value of 407 microsiemens per centimeter $(\mu \mathrm{S} / \mathrm{cm})$ at 25 degrees Celsius was recorded at Northeast Creek near Genlee (site 23) on March 10, 2011. The next four highest conductance 

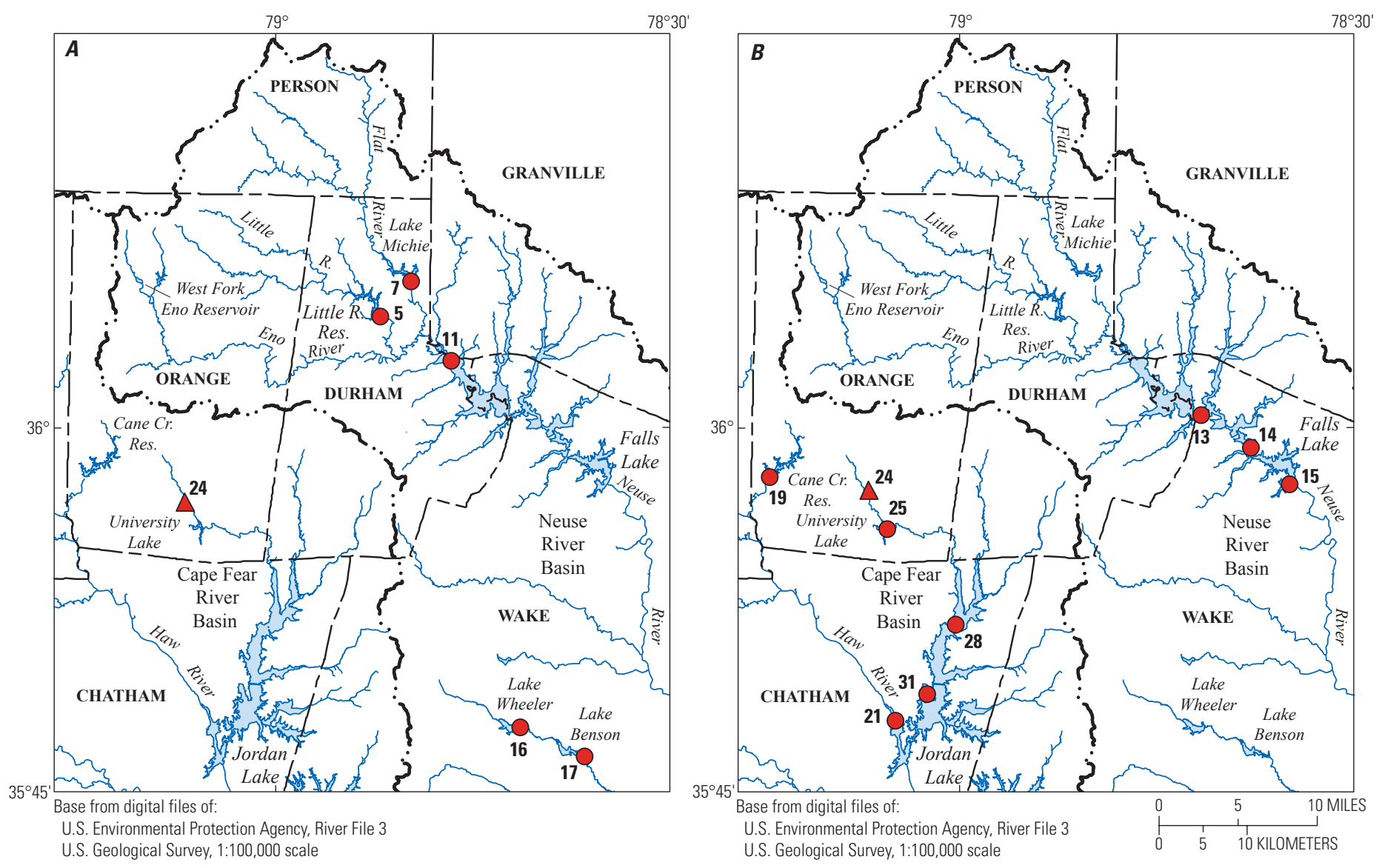

\section{EXPLANATION}

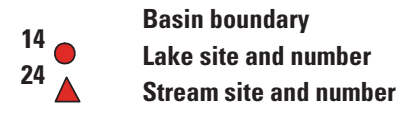

Figure 6. Sites in the Triangle area of North Carolina with one or more measurement of $A$, dissolved-oxygen concentration less than 5 milligrams per liter and $B$, dissolved-oxygen percent saturation values greater than 110 percent, October 2009 through September 2011. (See table 1; station locations are shown in figure 1.) 
readings were measured at Jordan Lake, Haw River arm (site 21). White Oak Creek (site 29) had the lowest conductance value of $47 \mu \mathrm{S} / \mathrm{cm}$ on August 5, 2010. Lake Butner (site 7) continued to have the lowest conductance values among the study lakes in water years 2010 and 2011 (table 3). Cane Creek Reservoir (site 19) had the greatest water transparency in water year 2010, and West Fork Eno Reservoir (site 1) had the greatest water transparency in water year 2011.

\section{Metals and Trace Elements}

Metals and trace element samples were collected twice per year at all stream and lake sites. In addition, iron and manganese were monitored at multiple depths during each lake sampling event.

The State aquatic-life standard for total recoverable iron is 1,000 micrograms per liter $(\mu \mathrm{g} / \mathrm{L})$; however, the NCDWQ is proposing to eliminate this standard because iron occurs naturally in the State's waters (North Carolina Department of Environment and Natural Resources, 2010b). Iron concentrations were higher than $1,000 \mu \mathrm{g} / \mathrm{L}$ at 12 stream sites and two lake sites in the study area during water years 2010 and 2011 (table 3; fig. 7A). As seen in previous water years, stormrelated (runoff) stream samples consistently were above the threshold. Approximately 34 percent of the iron concentrations $>1,000 \mu \mathrm{g} / \mathrm{L}$ occurred during non-runoff sampling events. Iron concentrations in lake surface samples were less than $1,000 \mu \mathrm{g} / \mathrm{L}$, except for selected samples collected at Falls Lake at U.S. Interstate 85 (site 11) and West Fork Eno Reservoir (site 1; table 3). Total recoverable manganese occasionally were above the $200 \mathrm{mg} / \mathrm{L}$ water-supply threshold at 11 lake sites and 10 stream sites during water years 2010 and 2011 (table 3; fig. $7 B$ ). Iron and manganese tend to be substantially higher in the lake bottom samples than near-surface samples during summer stratification (U.S. Geological Survey, 2015b). Iron and manganese generally are higher in streams during run-off events compared to base-flow conditions.
Eight stream and 11 lake sites had total recoverable mercury concentrations above the State threshold of $0.012 \mu \mathrm{g} / \mathrm{L}$ (table 3; fig. 7C). A maximum concentration of $0.070 \mu \mathrm{g} / \mathrm{L}$ was recorded at Cane Creek Reservoir (site 19) on April 22, 2011 (appendix 3). All mercury concentrations were less than the Federal drinking-water MCL of $2 \mu \mathrm{g} / \mathrm{L}$.

Copper concentrations greater than the State waterquality action level of $7 \mu \mathrm{g} / \mathrm{L}$ were measured at two lake and six stream sites. For the stream sites, all samples with more than $7 \mu \mathrm{g} / \mathrm{L}$ of copper were collected in association with runoff events (table 3; fig. 7D). All runoff samples collected at Knap of Reeds Creek (site 9) and Ellerbe Creek (site 10) were greater the State water-quality action level for copper. A maximum copper concentration of $16.7 \mu \mathrm{g} / \mathrm{L}$ was recorded at Ellerbe Creek on November 11, 2009 (appendix 3).

Concentrations of zinc above the State water-quality action level of $50 \mu \mathrm{g} / \mathrm{L}$ occurred at Ellerbe Creek near Gorman (site 10) on November 11, 2009 (77.1 $\mu \mathrm{g} / \mathrm{L}$ ), May 14, 2011 $(72.5 \mu \mathrm{g} / \mathrm{L})$, and July 8, $2011(62.1 \mu \mathrm{g} / \mathrm{L})$. Ellerbe Creek also was the only site with concentrations of silver greater than the State water-quality action level of $0.06 \mu \mathrm{g} / \mathrm{L}$, which occurred on November 11, $2009(0.170 \mu \mathrm{g} / \mathrm{L})$, September 27, 2010 $(0.084 \mu \mathrm{g} / \mathrm{L})$, May 14, $2011(0.124 \mu \mathrm{g} / \mathrm{L})$, and July 8, 2011 $(0.110 \mu \mathrm{g} / \mathrm{L})$. In regards to the State water-quality action levels for zinc and silver, the concentrations above the thresholds were in association with runoff events.

With the exception of aluminum, iron, and manganese, all metal and trace element concentrations met Federal drinking-water MCLs or SDWRs (table 3) during 2010 and 2011. As noted previously, MCLs and SDWRs are applicable to treated drinking water rather than untreated source water and are included for reference in this report. Aluminum, iron, and manganese frequently exceeded SDWRs (table 3) though concentrations were similar to those observed in the study area during previous years (U.S. Geological Survey, 2015). 
Water Quality
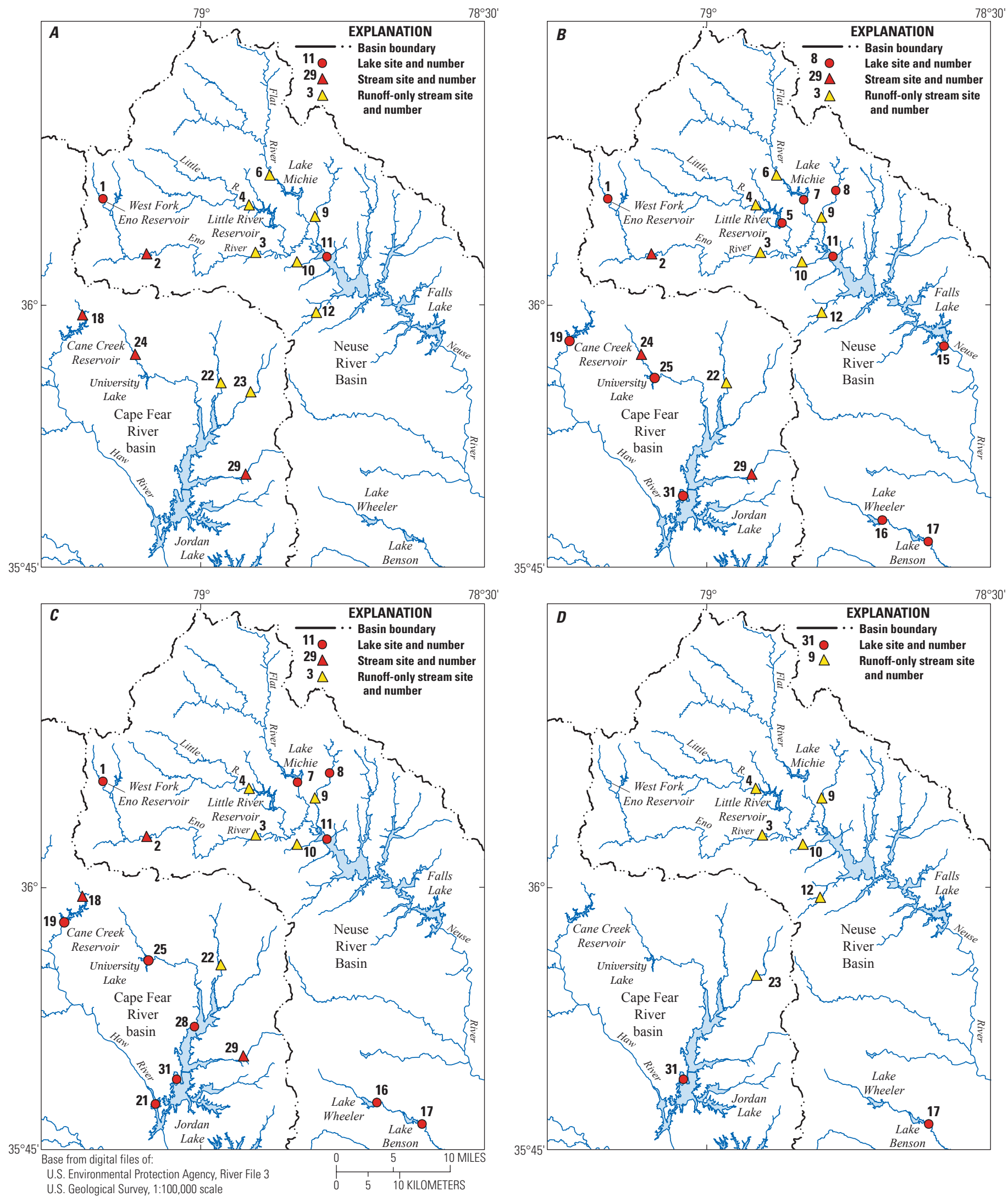

Figure 7. Sites in the Triangle area of North Carolina with one or more concentration of $A$, unfiltered iron greater than 1,000 micrograms per liter, $B$, unfiltered manganese greater than 200 micrograms per liter, $C$, unfiltered mercury greater than 0.012 microgram per liter, and $D$, unfiltered copper greater than 7 micrograms per liter, October 2009 through September 2010. (See table 1; station locations are shown in figure 1.) 


\section{Nitrogen and Phosphorus}

The USGS collected nutrient samples six times per year at four routine stream sites, four to six times per year at 16 lake sites, and during every sampling of runoff stream sites. Nutrient species that were analyzed included total ammonia plus organic nitrogen (also known as total Kjeldahl nitrogen), ammonia, nitrite, nitrate plus nitrite, orthophosphate, and total phosphorus. A State water-quality standard exists only for nitrate plus nitrite $(10 \mathrm{mg} / \mathrm{L})$. Nitrate plus nitrite concentrations ranged from near or below the reporting level at several lake sites to the maximum observed concentration of $2.29 \mathrm{mg} / \mathrm{L}$ at Northeast Creek near Genlee (site 23; table 3); consequently, the nitrate threshold was never exceeded.

Total ammonia plus organic nitrogen concentrations ranged from $0.17 \mathrm{mg} / \mathrm{L}$ at Morgan Creek near White Cross (site 24) to $2.3 \mathrm{mg} / \mathrm{L}$ at Ellerbe Creek (site 10) and varied widely among sites and sampling dates (table 3 ). Total nitrogen values were computed by summing ammonia plus organic nitrogen and nitrate plus nitrite. These computations were performed automatically by algorithms embedded in the USGS NWIS database. The left-censored $(<)$ remark code was retained with the computed total nitrogen value if one of the constituents used in the algorithm was below $0.016 \mathrm{mg} / \mathrm{L}$ for nitrate plus nitrite or below $0.10 \mathrm{mg} / \mathrm{L}$ for ammonia plus organic nitrogen. The censoring level associated with nitrate plus nitrite $(0.016 \mathrm{mg} / \mathrm{L})$ has minimal significance on the computed values for total nitrogen. In comparison, the minimum ammonia plus organic nitrogen concentration was $0.17 \mathrm{mg} / \mathrm{L}$, which is an order of magnitude greater than the value associated with nitrate plus nitrite. The $<$ remark codes were disregarded for the purpose of data assessment (fig. $8 A$ ).

Among lake sites, the highest concentrations of total nitrogen were observed at Jordan Lake, Haw River arm (site 21). Ellerbe Creek (site 10) had the highest observed concentrations of total nitrogen among stream sites. All storm-event stream samples had total nitrogen concentrations greater than $1.0 \mathrm{mg} / \mathrm{L}$ (fig. $8 A$; table 3 ).
Total phosphorus concentrations ranged from $0.011 \mathrm{mg} / \mathrm{L}$ at Lake Butner (site 8) to $0.654 \mathrm{mg} / \mathrm{L}$ at Ellerbe Creek (site 10). Storm-event samples frequently had concentrations greater than $0.20 \mathrm{mg} / \mathrm{L}$ (fig. $8 B$ ). Relatively lower concentrations (less than or equal to $0.05 \mathrm{mg} / \mathrm{L}$ ) generally were recorded at the four routine stream sites, several small reservoirs, three sites in Falls Lake, and two sites in Jordan Lake (fig. 8B). Among lake sites, the highest concentrations of total phosphorus generally were observed at Falls Lake at U.S. Interstate 85 (site 11) and Jordan Lake, Haw River arm (site 21; fig. 8B).

Concentrations of dissolved ammonia, nitrite, nitrate plus nitrite, and orthophosphate were less than laboratory reporting levels in 32, 27, 32, and 17 percent of samples, respectively. Most reportable concentrations were noted in streams throughout the year (table 3). The highest concentration reported for ammonia was $1.02 \mathrm{mg} / \mathrm{L}$ at Eno River at Hillsborough (site 2) observed on June 15, 2010. For nitrate plus nitrite, the highest concentration in the study area $(2.29 \mathrm{mg} / \mathrm{L})$ was observed at Northeast Creek near Genlee (site 23) on March 10, 2011. The maximum concentrations of orthophosphate $(0.303 \mathrm{mg} / \mathrm{L})$ and total phosphorus $(0.654 \mathrm{mg} / \mathrm{L})$ were observed at Ellerbe Creek near Gorman (site 10) on July 8, 2011 (appendix 3).

As in previous years, lake sites generally had low concentrations of dissolved ammonia, nitrite, nitrate plus nitrite, and orthophosphate near the water surface during summer months when these inorganic nutrient species tend to be taken up by phytoplankton. The somewhat riverine site 20, Jordan Lake, Haw River arm, was an exception. Nitrate plus nitrite was above reporting levels during all 12 sampling events, ranging from 0.219 to $1.46 \mathrm{mg} / \mathrm{L}$ (appendix 3). Bottom-water concentrations of ammonia, orthophosphate, and total phosphorus were higher than near-surface concentrations during the summer, when lakes were thermally stratified, and were consistent with results from previous years (U.S. Geological Survey, 2015). 

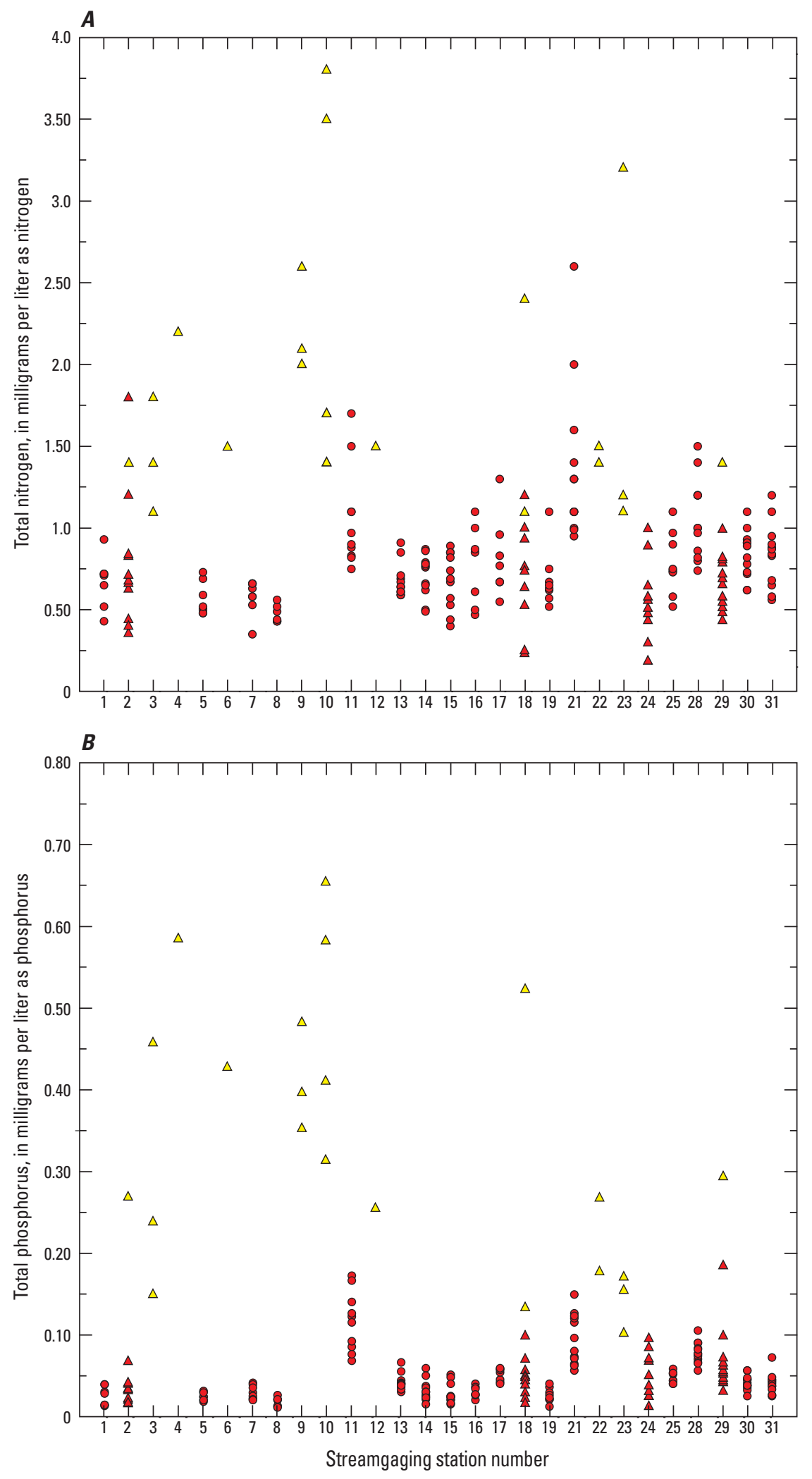

\section{EXPLANATION}

- Lake site routine sample

$\Delta$ Stream site routine sample $\Delta$ Stream site runoff sample

Figure 8. Concentrations of $A$, total nitrogen and $B$, total phosphorus at sampled sites in the Triangle Area Water Supply Monitoring Project study area, October 2009 through September 2011. (See table 1; station locations are shown in figure 1.) 


\section{References}

American Society for Testing and Materials (ASTM), 2002, Method D3977-97, Standard test methods for determining sediment concentration in water samples: West Conshohocken, Pa., ASTM International.

Clesceri, L.S., Greenberg, A.E., and Eaton, A.D., 1998a, Method 5310B, High temperature combustion, in Standard Methods for the Examination of Water and Wastewater (20th ed.): Washington, D.C., American Public Health Association, American Water Works Association, and Water Environment Federation.

Clesceri, L.S., Greenberg, A.E., and Eaton, A.D., 1998b, Method 3120, Metals in water by plasma emission spectroscopy, in Standard Methods for the Examination of Water and Wastewater (20th ed.): Washington, D.C., American Public Health Association, American Water Works Association, and Water Environment Federation.

Fishman, M.J., ed., 1993, Methods of analysis by the U.S. Geological Survey National Water Quality LaboratoryDetermination of inorganic and organic constituents in water and fluvial sediments: U.S. Geological Survey Open-File Report 93-125, 217 p.

Fishman, M.J., and Friedman, L.C., eds., 1989, Methods for determination of inorganic substances in water and fluvial sediments: U.S. Geological Survey Techniques of WaterResources Investigations, book 5, chap. A1, 545 p.

Garbarino, J.R., and Damrau, D.L., 2001, Methods of analysis by the U.S. Geological Survey National Water Quality Laboratory-Determination of organic plus inorganic mercury in filtered and unfiltered natural water with cold vapor-atomic fluorescence spectrometry: U.S. Geological Survey Water-Resources Investigations Report 01-4132, $16 \mathrm{p}$.

Garbarino, J.R., Kanagy, L.K., and Cree, M.E., 2006, Determination of elements in natural-water, biota, sediment and soil samples using collision/reaction cell inductively coupled plasma-mass spectrometry: U.S. Geological Survey Techniques and Methods, book 5, chap.1, sec. B, 88 p.

Garbarino, J.R., and Struzeski, T.M., 1998, Methods of analysis by the U.S. Geological Survey National Water Quality Laboratory - Determination of elements in wholewater digests using inductively coupled plasma-optical emission spectrometry and inductively coupled plasmamass spectrometry: U.S. Geological Survey Open-File Report 98-165, $101 \mathrm{p}$.

Giorgino, M.J., Rasmussen, R.A., and Pfeifle, C.A., 2012, Quality of surface-water supplies in the Triangle area of North Carolina, water year 2008: U.S. Geological Survey Open-File Report 2012-1013, 12 p.
Hambrook Berkman, J.A., and Canova, M.G., 2007, Algal biomass indicators (ver. 1.0): U.S. Geological Survey Techniques of Water-Resources Investigations, book 9, chap. A7, sec. 7.4, August 2007, accessed September 17, 2015, at http://pubs.water.usgs.gov/twri9A7/.

North Carolina Department of Environment and Natural Resources, Division of Water Quality [Division of Water Resources], 2007, Surface waters and wetlands standards (May 1, 2007), NC Administrative Code 15A NCAC 2B: Raleigh, Environmental Management Commission, 134 p., accessed July 7, 2011, at http://portal.ncdenr.org/c/ document_library/get_file?uuid=b399d1e0-0a9e-4dcc9605-a673d8a5c6df\&groupId=38364.

North Carolina Department of Environment and Natural Resources, Division of Water Quality [Division of Water Resources], 2010a, 2008 North Carolina integrated report categories 4 and 5 (impaired waters list), March 10, 2010: Raleigh, North Carolina, North Carolina Division of Water Quality, 139 p., accessed September 11, 2012, at http://portal.ncdenr.org/web/wq/ps/mtu/assessment.

North Carolina Department of Environment and Natural Resources, Division of Water Quality [Division of Water Resources], 2010b, Proposed changes to NC aquatic life standards for metals, March 2010: Raleigh, North Carolina, Environmental Management Commission, accessed September 11, 2012, at http://portal.ncdenr.org/web/wq/ps/ $\mathrm{csu} / \mathrm{sw}$ trirev.

North Carolina Department of Environment and Natural Resources, Division of Water Quality [Division of Water Resources], 2015b, North Carolina's Surface Water Quality Standards, accessed January 9, 2015, at http://portal.ncdenr.org/web/wq/ps/csu/swstandards.

Oblinger, C.J., 2004, Triangle Area Supply Monitoring Project, October 1988 through September 2001, North Carolina-Description of the water-quality network, sampling and analysis methods, and quality-assurance practices: U.S. Geological Survey Open-File Report 2004-1278, 56 p.

Palmer, W.C., 1965: Meteorological drought: U.S. Weather Bureau, Research Paper No. 45, 58 p.

Patton, C.J., and Truitt, E.P., 2000, Methods of analysis by the U.S. Geological Survey National Water Quality Laboratory-Determination of ammonium plus organic nitrogen by a Kjeldahl digestion methods and an automated photometric finish that includes digest cleanup by gas diffusion: U.S. Geological Survey Open-File Report 00-170, 31 p.

Pfeifle, C.A., Giorgino, M.J., and Rasmussen, R.B., Quality of surface-water supplies in the Triangle area of North Carolina, water year 2009: U.S. Geological Survey OpenFile Report 2014-1192, 13 p., accessed September 11, 2014, at http://dx.doi.org/10.3133/ofr20141192. 
Radtke, D.B., Davis, J.V., and Wilde, F.D., 2005, Specific conductance (ver. 1.2): U.S. Geological Survey Techniques of Water-Resources Investigations, book 9, chap. A6, sec. 6.3, August 2005, accessed September 17, 2015, at http://pubs.water.usgs.gov/twri9A6/.

Ritz, G.F., and Collins, J.A., 2008, pH (ver. 2.0): U.S. Geological Survey Techniques of Water-Resources Investigations, book 9, chap. A6, sec. 6.4, October 2008, accessed September 17, 2015, at http://pubs.water.usgs.gov/twri9A6/.

Rounds, S.A., 2012, Alkalinity and acid neutralizing capacity (ver. 3.0): U.S. Geological Survey Techniques of Water-Resources Investigations, book 9, chap. A6., sec. 6.6, September 2012, accessed May 17, 2013, at http://pubs.water.usgs.gov/twri9A6/.

Rounds, S.A., 2013, Alkalinity calculation methods, accessed September 17, 2015, from http://or.water.usgs.gov/alk/methods.html.

Rounds, S.A., Wilde, F.D., and Ritz, G.F., 2013, Dissolved oxygen (ver. 3.0): U.S. Geological Survey Techniques of Water-Resources Investigations, book 9, chap. A6., sec. 6.2, September 2013, accessed September 17, 2015, at http://pubs.water.usgs.gov/twri9A6/.

State Climate Office of North Carolina, 2012a, Climate Division Data, accessed September 17, 2012, at http://www.nc-climate.ncsu.edu/climate/climdiv.php.

State Climate Office of North Carolina, 2012b, NC CRONOS database, accessed August 23, 2012, at http://www.nc-climate.ncsu.edu/cronos.
U.S. Environmental Protection Agency, 1993, Method 365.1, Determination of phosphorus by semi-automated colorimetry, revision 2.0: Cincinnati, Ohio, U.S. Environmental Protection Agency, Office of Research and Development, $17 \mathrm{p}$.

U.S. Environmental Protection Agency, 2015, Drinking water contaminants: U.S. Environmental Protection Agency, accessed February 13, 2015, at http://www.epa.gov/safewater/contaminants/index.html.

U.S. Geological Survey, 2006, Collection of water samples (ver. 2.0): U.S. Geological Survey Techniques of Water-Resources Investigations, book 9, chap. A4, September 2006, accessed March 19, 2014, at http://pubs.water.usgs.gov/twri9A4/.

U.S. Geological Survey, 2015, Annual Water Data Report Series, accessed March 10, 2015, at http://nc.water.usgs.gov/reports/WDR/.

Wilde, F.D., 2006, Temperature (ver. 2.0): U.S. Geological Survey Techniques of Water-Resources Investigations, book 9, chap. A6, sec. 6.1, March 2006, accessed September 17, 2015, at http://pubs.water.usgs.gov/twri9A6/.

Wilde, F.D., Radtke, D.B., Gibs, Jacob, and Iwatsubo, R.T., eds., 2004, Processing of water samples (ver. 2.1): U.S. Geological Survey Techniques of Water-Resources Investigations, book 9, chap. A5, accessed October 2, 2007, at http://pubs.water.usgs.gov/twri9A5/. 
Manuscript approved on January 6, 2016

For further information about this publication contact:

Director

South Atlantic Water Science Center

U.S. Geological Survey

720 Gracern Road

Columbia, SC 29210

http://www.usgs.gov/water/southatlantic/

Prepared by the Raleigh Publishing Service Center 


\section{曾}

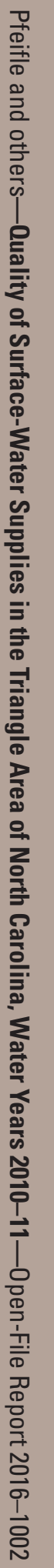

